\title{
Communication Strategy in Increasing Compliance of Property Tax in Bandung City
}

\author{
Adhli Al-Afwan Izwar ${ }^{1}$, Abdul Rahman ${ }^{2}$, Deddy Mulyadi ${ }^{3}$, Edah Jubaedah $^{4}$ \\ Politeknik STIA LAN Bandung, Jl. Cimandiri 34-38 Bandung 40115234 \\ \{adhlidilgi@gmail.com ${ }^{1}$ \}
}

\begin{abstract}
Compliance with paying taxes, especially property taxes, is a problem that is most often felt by the Bandung City Regional Revenue Agency (Bapenda). In the last three years, the tendency of the percentage of receipts on time or before due date year has never reached $80 \%$ of the achievement standard. Communication is an important factor in increasing public awareness, knowledge, and compliance. To address this issue, this study investigates the communication implementation strategy of Bapenda to Bandung City community by analyzing qualitatively the form, technique, message content, and the effect of communication to the Bandung City community. Using SWOT analysis, the communication implementation strategy used by the Bapenda is the SO strategy, where the Bandung City Bapenda integrates traditional communication models to become triggers for digital media, uses official digital media to communicate to the public, and empowers RW/RT administrators to become Bapenda's communication agents.
\end{abstract}

Keywords: Communication, communication strategy, tax compliance, property tax

\section{Introduction}

When compared to other taxes and levies, land and building taxes, generate the largest and most significant municipal revenue in terms of regional income. The land and building tax have a total of 12,366 corporate taxpayers and 390,744 individual taxpayers. According to Bandung City Regional Revenue Agency (Bapenda) data, land and building taxes account for $43 \%$ of total municipal revenue, making it the highest of all local taxes in the city. When there is an issue in collecting land and building taxes, it will have the effect on the city's development. As a result, it is critical for Bandung City Regional Revenue Agency (Bapenda) to pay close attention to trends in land and building tax receipts.

According to the Institute for Development of Economics and Finance (INDEF), Indonesia's tax challenges are generally ineffective taxation programs, insufficient taxation human resources, pro-business tax policy issues, fiscal relaxation inefficiency and ineffectiveness, and a low degree of compliance [1]. Additionally, it was said that tax compliance decreased significantly from 72.6 percent in 2017 to only 67.4 percent in 2019. 
Counseling and socialization, according to [2], are critical components of enhancing community awareness, knowledge, and compliance. Socialization and outreach initiatives are a means of contact between Bandung City Regional Revenue Agency (Bapenda) and the community and are critical in raising public awareness and knowledge. Thus, it is critical to understand how Bandung City Bapenda has conducted socialization and counselingin the past and how this has impacted the community.

Furthermore, the current decline in public compliance with taxation is a result of the Bandung City Bapenda's ineffective communication methods and media. This is evident in the interview findings with Mr. Cahyo, who has been in tax arrears for four years. According to him, the primary reason for the delay was the difficulties in acquiring information about payment procedures. Additionally, he stated, his failure to manage the delay was causedby a lack of information about tax reminders, despite of the fact that Bandung City Bapenda had advertised informationabout the maturity of land and building tax payments in a variety of media outlets, including newspapers, radio, television, and online news portals. Which demonstrates that there is an issue with the selection of communication means through which the public cannot access the information distributed by the Bandung City Bapenda.

Based on forementioned phenomena, it is noticeable that taxpayers' awareness and understanding regarding regular payments remain low due to a lack of adequate and efficient information. Counseling and socialization are critical for tax collectors to employ in terms of raising taxpayer awareness and understanding including to increase taxpayer compliance [2]. However, according to the research by the Bandung City Bapenda, communication and counseling activities have not been the primary focus, despite of the fact that they are conducted annually.

As a result, academics believe it is necessary to examine the Bandung City Bapenda communication strategy and its impact on society. This research can be used to determine how to optimize communication implementation, in this case the Bandung City Bapenda socialization program, by analyzing previous socialization implementation to ascertain environmental factors and then developing appropriate communication strategies for the community, particularly in the city of Bandung.

\section{Literature Review}

In Indonesia, the present tax collecting system is a hybrid of self-assessment and withholding, with the authorityto calculate the amount of tax payable resting not only with the tax authorities and individuals, but also with third parties [3]. The tax authorities calculate the total amount of tax due, whereas the taxpayer and third parties estimate the total amount of tax installments. Thus, the system's essence is voluntary compliance, in which taxpayers exercise their tax rights and responsibilities voluntarily and are fully aware of the repercussions of their infractions [4], [5].

Socialization and counseling are pre-requisites for increasing taxpayer awareness [2], [6] and knowledge [2], [7]. Socialization and counseling have a direct effect on taxpayer knowledge and compliance, as well as acting as a catalyst for the relationship between increasing knowledge and taxpayer compliance [8]. Socialization and counseling also have a direct effect on taxpayer awareness and compliance including serve as a catalyst for increased awareness of taxpayer 
compliance, particularly related to land and building taxes [9].

There are two types of communication: linear and transactional [10]. Linear communication is a one-way communication model in which the sender encodes a message and then transmits it to the recipient through a channel, either vocal or non-verbal. When the communication is delivered, noise occurs that may obstruct the recipient from getting the message. Thus, the linear communication model's constituents are sender, message, channel, receiver, and noise. One of the most frequently thrown objections against the Linear Communication Model is that it assumes communication occurs entirely in one direction and fails to explain how context, as well as our own personal experiences, influence communication.

Public communication is the act of disseminating information to a large group of people within an organization or to the entire public [11]. Public communication is distinct from other forms of communication in that the listener is typically passive, the engagement between the communication's participants is limited, and the response supplied is likewise limited. As a result, government communication with the public must be transparent, direct, and inclusive, utilizing all appropriate channels of communication, avoiding internal and external disputes, and stressing neutrality as a state apparatus. To accomplish it, advertisers must exhibit the following skills: the ability to communicate effectively, pay close attention, provide timely feedback, demonstrate the proper and accurate use of products or services, have a strong character, and be able to develop longterm connections. lengthy interactions with taxpayers.

Organizations develop communications to be more effective in communication, where the message must first attract attention, which then generates interest, arouses desire, and ultimately results in action - whether to buy or not to buy. It is also necessary to know how consumers behave while they are seeking information, utilizing, reviewing, or replacing a product or service when developing a marketing communication strategy [12].

Organizations integrate these three factors to influence a person's behavior while making decisions, whether it's a purchase decision or something more substantial [13]. When integrating it, organizations must pay close attention to the integration process's fit with the target's personality, as this will have effect on the outcome of the communication objectives. Integration errors can prevent the desired behavior change from occurring or possibly have no effect on the communication target.

\section{Research Framework}

According to study on taxpayer compliance with the requirement to pay Land and Building Tax (PBB) on time, the services obtained by taxpayers have a beneficial effect on compliance with the requirement to pay on time [14], [15]. Additionally, awareness, knowledge, and comprehension, as well as counseling, all contribute to taxpayer compliance with the requirement to pay $\mathrm{PBB}$ on time [14]; [18].

Public services are not solely dictated by the renewal and restructuring of sectoral bureaucracies in their execution [19]. All economic classes must be covered by policies that are effective, efficient, and competitive. To dothis, bureaucratic behavior must be contemporary [20] and responsive to the needs of the people it serves. 
For the community, accessibility and clarity of information are critical, and for the government, this is a component of information openness to earn the community's trust and admiration for its performance. Not only do people demand exceptional service based on sound administration, but they also want a clean government, easy access to information, and a speedy connection to the stakeholders they desire [21].

To address the forementioned issues and promote taxpayer compliance with timely tax payments, a strategic instrument is required, namely a communication and socialization strategy, as a manifestation of one of the primary elements affecting taxpayer compliance. This strategy transparently and accountability includes communication aspects. This tool necessitates the development of work programs based on an integrated communication strategy. It is intended that this communication strategy will raise taxpayer awareness and knowledge, which will ultimately result in people paying taxes on time, particularly land and construction taxes. Based on the foregoing, a framework of thought is developed, as seen in Figure 1.

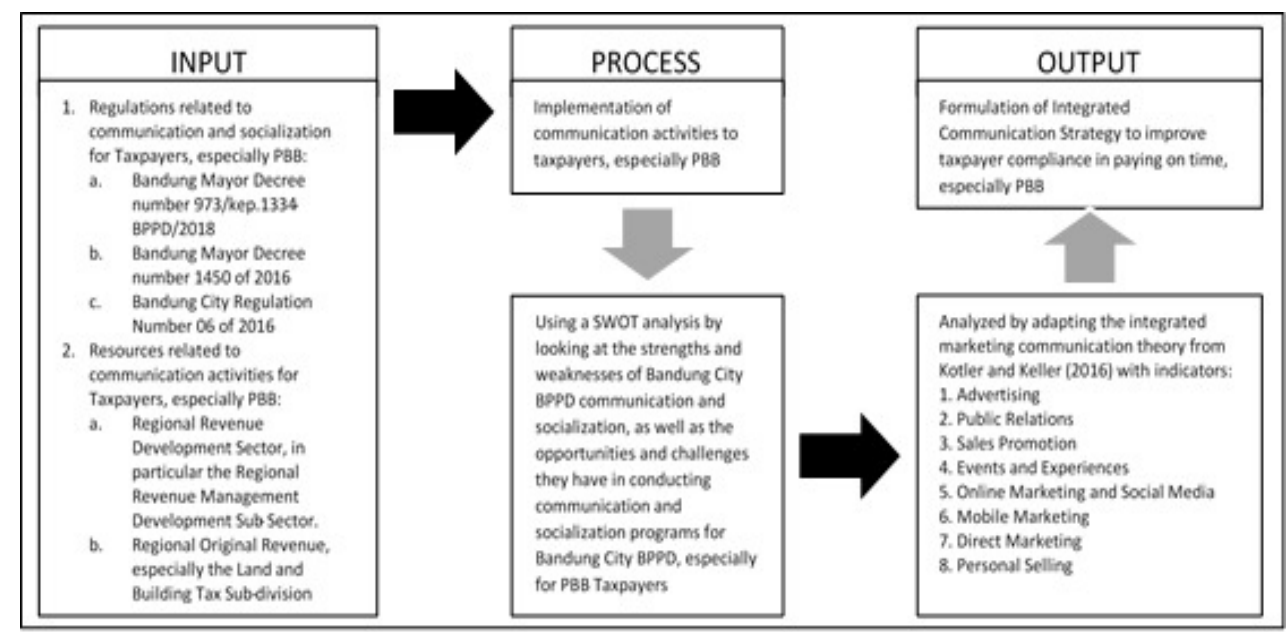

Fig 1. Research Framework

This research takes as its starting point the existence of regulations governing communication and socializing for taxpayers, most notably land and construction taxes. Bandung Mayor Decree number 973/kep.1334-BPPD/2018 establishes standard operating procedures for Bandung City Bapenda services. Bandung Mayor Regulation 1450 of 2016 establishes the organizational structure of the Bandung City Regional Revenue Management Agency, and Bandung City Regional Regulation 062016 establishes the framework for this research. Additionally, the Regional Revenue Development Division, specifically the Regional Revenue Management Development Sub-Section, and theRegional Original Revenue Sector, specifically the Land and Building Tax Sub-Section, are resources for Bandung City Bapenda communication operations with taxpayers.

According to these two criteria, the researchers conducted an analysis of the execution of communication initiatives for taxpayers, focusing on land and building taxes, which were then seen through the lens of influencing factors using a SWOT analysis. The findings of this research will be 
used to develop an integrated communication plan based on Kotler and Keller's notion of integrated marketing communication [22]. Thus, Bandung City Bapenda might adopt this communication strategy to communicate and socialize with the public to increase taxpayer compliance with tax payments, particularly land and building taxes.

\section{Methodology}

The type of study that will be performed is descriptive research, in which the data obtained will be examined and conclusions drawn based on field facts. The approach is inductive, utilizing a mixed strategy. The study will be conducted using primary data from interviews and secondary data from a collection of reports on Bapenda's socializing activities in Bandung. The analysis's conclusions will be used to develop a communication strategy basedon the field's findings utilizing the SWOT analysis approach. The SWOT matrix is used to quantitatively determine alternative plans by weighting internal and external elements.

\section{$5 \quad$ Result}

The data on socializing activities obtained include papers pertaining to socialization events conducted between 21 July and 12 October 2019. According to these documents, Bandung City Bapenda conducted 61 socialization andcommunication initiatives through events, newspapers, radio, television, and websites. Figure 2 below illustrates data on media consumption.

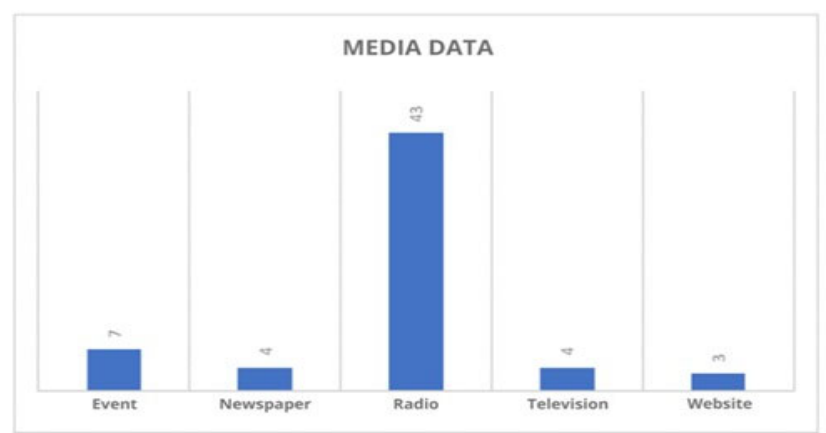

Fig 2. Media Data

Bandung City Bapenda, specifically the Regional Revenue Development Sector, Sub-Division of Regional Revenue Management Development, has implemented a variety of programs to distribute information to the community. According to the KAK document for Socialization Activities prepared by the Bandung City Bapenda's Planning and Extension Division, the socialization activity's objective is to raise public awareness and knowledge about the necessity of tax payment. 
When asked about the performance indicators for these operations, the head of the Planning and Extension Division said that he lacked a specific metric. Bandung City Bapenda does not have a dedicated team responsible for community interactions and communication. Socialization responsibilities and activities are delegated to the Planning and Extension Sector, giving the impression that this is not a priority.

\subsection{Internal and External Factor Analysis}

Strengths

Bandung City Bapenda has been utilizing media as a means of mass and personal communication. Newspapers, radio, television, news portal and official websites, events, social media platforms such as Twitter and Instagram, outdoor media such as billboards and billboards, and personal chat platforms such as Whatsapp are all examples of recorded media. Additionally, collaboration with other agencies such as sub-districts, RT, and RW has been developed to assist in the dissemination of the SPPT PBB to the general publics or taxpayers.

This is consistent with the statement of Bapenda Bandung's Head of Regional Revenue Development Division, who indicated that they have used these media in the past, including events hosted in various locations throughout the city. Additionally, he stated that Bandung City Bapenda has partnered with numerous agencies, including sub-districts within the city limits, to distribute land and building tax SPPT, as well as West Java Bankand other agencies, to serve as a location for land and building tax payment. The Subdistrict Head (Camat) of Bandung Wetan also discussed the existing cooperation between Bandung City Bapenda and the sub-district, although it was later said that it was still important to focus on a win-win solution for all parties.

Another strength is that the Bandung City Regional Revenue Agency is the only entity authorized to collect local taxes in Bandung, most notably land and construction taxes. It controls the role and function of the Bandung City Regional Revenue Agency in managing local taxes, in accordance with Law No. 23 of 2014 and Bandung Mayor Regulation No. 22 of 2021. As a result, the Bandung City Regional Revenue Agency is also responsible for the administration of information pertaining to this topic.

\section{Weaknesses}

Despite the division's usage of a variety of communication channels, the Regional Revenue Development Division continues to prioritize advertising and event communication strategies. This is one of the Bandung City Regional Revenue Agency communication shortcomings. This field employs only event media to distribute information about regional taxation; event attendees serve as representatives of the invitation and are not open to the public. The event's idea is more ceremonial in character and does not place a premium on public education.

Additionally, various media are utilized solely to publicize the tax payment due date schedule. Without tax-related articles or information dissemination activities such as radio talk programs, the task of sharing beneficial information became invisible. In other words, they lack the capacity to give accurate and effective information to the community through the medium they have. Additionally, the Regional Revenue Development Sector's operations have remained consistent year after year. The activity's format and concept remain consistent from year to year. Additionally, activity data is not adequately inventoried, with researchers receiving only 2019 data due to the 
absence of data for the years preceding and after. The prior activities remained unchanged from the 2019 statistics, and only event activities were canceledin 2020 owing to the COVID-19 pandemic. Thus, it can be argued that the socialization activities conducted in this field were inefficient and relied solely on the budget model from the previous year.

This shortcoming is a result of a lack of skilled human resources dedicated to public communication. Additionally, there is no dedicated team to handle this activity, despite of fact that communication is a critical component of sustaining stability and avoiding incorrect information or injuring the public in a public institution. Additionally, the lack of operational standards, technical instructions, and implementation instructions for this activity is a communication problem for the Bandung City Regional Revenue Agency.

The Bandung City Regional Revenue Agency inability to coordinate between fields and with other agenciesis another shortcoming. While the Regional Revenue Development Sector has the obligation and responsibility to connect with the community, other sectors have the power to disseminate information and serve as a forum for inquiries and concerns. For instance, the Bandung City Regional Revenue Agency social media accounts, which are controlled by other fields, the tax information service accounts, which are managed by each tax service sub-sector, and instances of other fields promoting themselves via outdoor media when they should not the Regional Revenue Development Sector's governing body.

There is also a lack of collaboration with parties outside the organization, such as the District, $\mathrm{RT}$, and RW. The sub-district and its apparatus believed they were being directed by the Regional Revenue Agency to distribute SPPT PBB that did not exist in the regional apparatus's organizational structure. The communication that is constructed is viewed as an order from superiors and subordinates, including is not constructed collaboratively.

Finally, the media outlets through which the Regional Revenue Development Sector communicates with the public are admittedly ineffective. Newspapers, radio, and television are admittedly inefficient means of delivering information. People no longer read newspapers or listen to the radio, according to the chairman of the Regional Revenue Development Division. Additionally, it is recognized that the lack of data on the media that people currently use prevents them from determining which media should be used to deliver information. Finally, they continue to practice the old habits solely to avoid fulfilling their commitments.

\section{Opportunities}

The potential that the Bandung City Regional Revenue Agency has in implementing communication is that taxpayers are aware of the need of paying taxes, based on the results of interviews with taxpayers. All interviewees believed that taxation is necessary for their prosperity. As a result, the tax payments they make contribute to regionaldevelopment. They are also aware that failing to pay taxes will result in a fine. As such, it should be mentioned thatit is not that they do not wish to pay taxes on time; rather, they frequently forget due to their hectic schedules.

Additionally, taxpayers appreciate that there are incentives for those who are careful and consistent in payingtheir taxes on time. The incentive can take the shape of tax rebates or other forms of compensation. This incentive could be utilized to assist the Regional Revenue Agency in communicating regional tax policies.

Additionally, their proclivity for using gadgets to gather information provides an opportunity for the BandungCity Regional Revenue Agency to communicate via digital and social media. Thus, 
the cost of adopting a communication plan might be lower and more effective when it involves direct contact with the individual. Additionally, people prefer personal communication to mass communication. As seen by the numerous inquiries discovered on Whatsapp chat media and social media, this is true.

Additionally, the informants said that they trusted the Regional Revenue Agency and RT/RW administrators who brought their PBB SPPT over other sources of information. This simplifies communication between the Regional Revenue Agency and other parties. By designating RT/RW administrators as Regional Revenue Agency agents, they can assist the Regional Revenue Agency in meeting taxpayers' information demands. Additionally, taxpayers anticipate in obtaining tax information from the Regional Revenue Agency's official websites and social media profiles.

This information can serve as a springboard for communication between the Regional Revenue Agency and the community. By educating the public on tax calculation and payment methods, it is possible for the Bandung CityRegional Revenue Agency to establish good communication with the community.

\section{Threats}

Although the data discovered imply a decline in Bandung's unemployment rate, the data cannot be claimed tobe genuine. This is because the data was collected prior to the COVID-19 epidemic in 2018. As it is generally perceived, the COVID-19 pandemic has had a profound effect on society's social and economic components. The number of enterprises that have closed and the number of layoffs lead researchers to believe that the rising unemployment rate poses a threat.

Additionally, the Bandung City Regional Revenue Agency has conducted various socialization and counseling programs as part of its engagement with the community. All taxpayer informants, on the other hand, acknowledged that they hardly never received socialization from the Bandung City Regional Revenue Agency. Onlytwo respondents claimed that they had once heard a radio commercial soliciting payment of unpaid land and construction taxes, and one responded that they had seen a billboard. This demonstrates that the public is unaware ofthe socialization efforts of the Bandung City Regional Revenue Agency and has developed an apathy toward taxation.

To obtain more precise information, the community is compelled to visit the Regional Revenue Agency office and speak directly with staff. This demonstrates that the communication channels utilized thus far have had little effect on raising public awareness and knowledge regarding municipal taxes. Additionally, this complicates and strains communication between the community and the Regional Revenue Agency. As a result, this circumstance jeopardizes the Bandung City Revenue Agency's communication.

Apart from being ambiguous, the Bandung City Regional Revenue Agency communication to date has been perceived as easy to forget, to impersonal, and to appears to deceive the people. For instance, the lack of transparency on the relaxation of land and building taxes poses a risk in the future when the relaxation is lifted. The informant made this complaint years ago during a meeting with the Bandung City Regional Revenue Agency, but there has been no follow-up to date.

Additionally, information is difficult for the public to get when it is needed. The RT/RW management was unable to give a solution because they lacked sufficient information to address the residents' concerns. Additionally, information media such as the Bandung City Regional Revenue Agency's websites and official social media accounts do not perform adequately in providing information services to the public. Finally, the community must return to the Regional Revenue 
Agency's service office to obtain the necessary information.

Upon conducting an examination of the internal and external aspects mentioned previously, an alternative strategy matrix was created based on the subjectivity and experience of researchers working Bandung city Bapenda. The alternative communication plan is depicted in Figure 3.

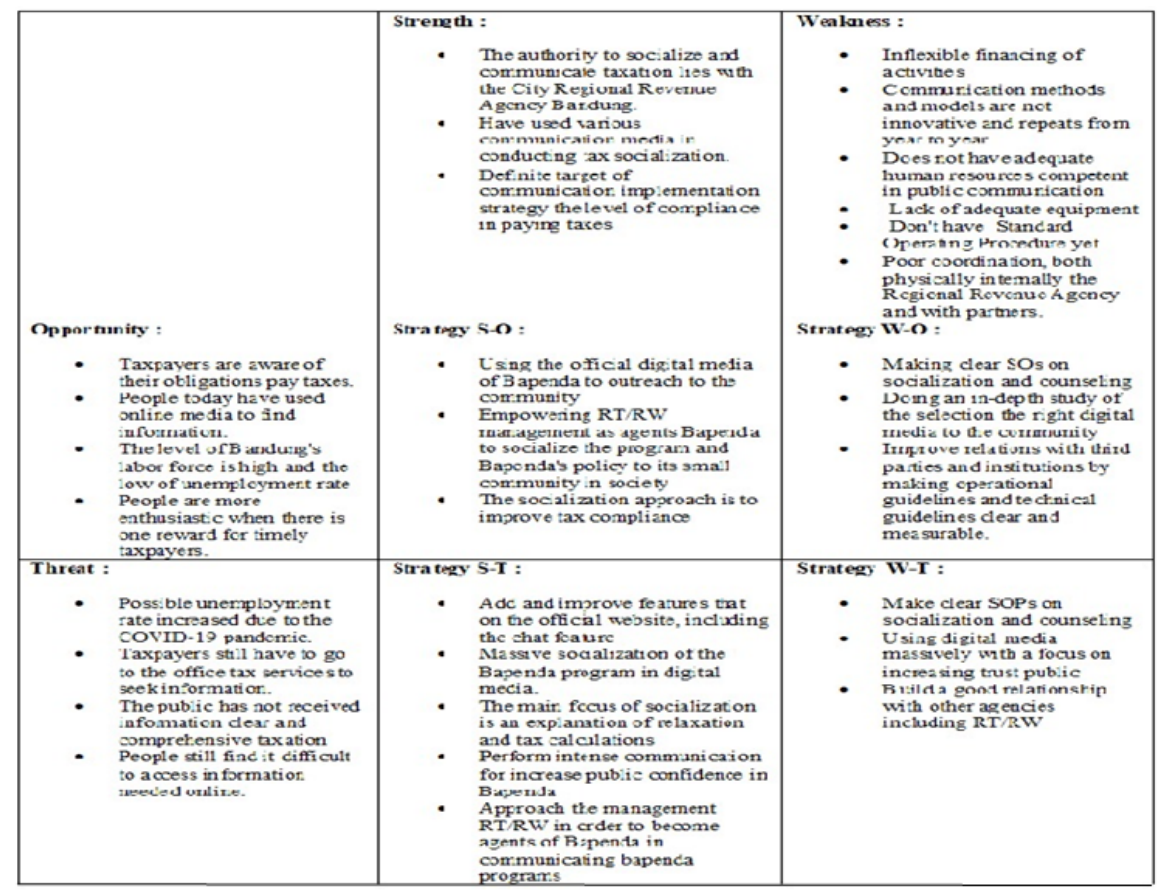

Fig 3. Alternatives Strategy

The researcher and a team from the property tax division of the Bandung City Regional Revenue Agency then weighted data on internal and external elements of strength and weakness, as well as opportunities and difficulties. The weighted values are then entered into a quadrant graph of a SWOT analysis to establish the strategy that will be prioritized at this moment. Figure 4 illustrates the weighted and quadrant results of the SWOT analysis.

As a result, an alternate approach that could be implemented at this moment is the S-O or aggressive strategy.This is because the resources used have remained constant, with the emphasis shifting to digital media. The media outlets that are now owned can be used to promote the Bandung City Regional Revenue Agency's websites and official social media accounts 's official website. Additionally, the Regional Revenue Development Division has handled the site. So that no major changes occur in the Regional Revenue Development Sector because of implementing this approach.

As illustrated in Figure 4, the Bandung City Regional Revenue Agency's websites and official social media accounts socialization and expansion strategy is in quadrant I. In this quadrant, an aggressive strategy is utilized to support an aggressive growth agenda. As a result, the Bandung City 
Regional Revenue Agency's socializing strategy leverages its strengths to create chances, notably the S-O Strategy.
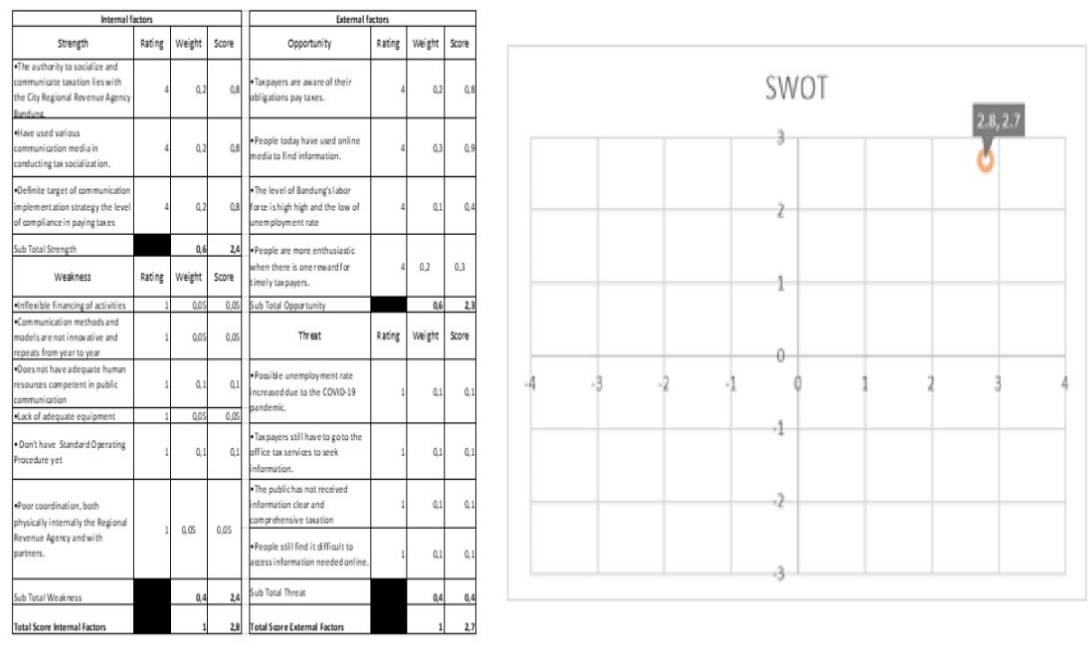

Fig 4. SWOT Analysis Matrix

Given that the chosen method must be implemented quickly and does not demand significant resources from the Bandung City Regional Revenue Agency, it is regarded appropriate. This is because the resources used have remained constant, with the emphasis shifting to digital media. The media outlets that are now owned can be used to promote the Bandung City Regional Revenue Agency's official website. Additionally, the Planning and Extension Division has overseen the site. Thus, there will be no fundamental changes to the Planning and Extension Sector as a result of implementing this approach.

\section{Conclusion and Recommendation}

Bandung City Bapenda's communication implementation has been ineffective in terms of media utilization, message integration, and communication strategies. Other departments may also conduct socialization operations to ensure that the message received is perceived by taxpayers as ambiguous, easily forgotten, and having little influence on them. Thus, it is critical for them to have a defined plan to accomplish the goal of spreading information, which is to increase taxpayer compliance with tax obligations, particularly land and construction taxes.

To overcome ineffective communication implementation, it is vital to have a clear communication plan. The communication strategy is developed after doing a SWOT analysis of the internal and external environments. Internal environmental analysis examines Bandung City Bapenda's strengths and limitations in communicating with taxpayers. While the external environment study is used to determine how taxpayers react to the implementation of the Bandung City Bapenda's communication efforts. An alternate strategy is then developed based on the analysis 
findings by merging two internal and external components. Bandung City Bapenda will select alternative tactics based on a weighted SWOT analysis matrix. The communication strategy chosen is aggressive, in which Bandung City Bapenda leverages its current capabilities to capitalize on chances. This choice is based on the notion that they will not require significant resource changes or additional funding to accomplish the strategy. Because, as a governmental entity, changing or creating something new requires a lengthy bureaucracy and a big expense.

As a result, the Bandung City Bapenda must combine its media outlets to act as information feeders to the official website. Making the official website of Bandung City Bapenda a resource center for tax calculations and payment procedures by providing articles on tax calculations and payment procedures. The articles created clarify indetail that they often asked questions during consultations via Whatsapp, removing the need for customers to seek information elsewhere or contact Bandung City Bapenda`s office.

Additionally, Bandung City Bapenda needs to make the Whatsapp communication channel the final port of call for taxpayers who do not understand the information offered on Bandung City Bapenda`s official website. Additionally, the Whatsapp communication channel serves as a forum for taxpayer consultation to build public confidence in Bandung City Bapenda. Whatsapp can thus serve as a reminder to taxpayers to pay taxes, hencereducing late payments.

Empowering $R T / R W$ administrators to act as agents for Bandung City Bapenda is a novel use of a personal selling communication model in which $R T / R W$ administrators are educated to act as a point of contact for taxpayers seeking advice on land and building taxes. Additionally, $R T / R W$ administrators will welcome citizens to access the official website of the Bandung City Regional Revenue Agency to obtain necessary information.

\section{References}

[1] B. Yadika, "5 Masalah Serius Yang Bikin Penerimaan Pajak Tak Tercapai," Liputan6.Com, 2019.Https://Www.Liputan6.Com/Bisnis/Read/4044652/5-Masalah-Serius-Yang-Bikin-PenerimaanPajak-Tak-Tercapai (Accessed Jul. 31, 2021).

[2] D. K. Wardani And E. Wati, "Pengaruh Sosialisasi Perpajakan Terhadap Kepatuhan Wajib Pajak Dengan Pengetahuan Perpajakan Sebagai Variabel Intervening (Studi Pada Wajib Pajak Orang Pribadi Di Kpp Pratama Kebumen)," Nominal, Barom. Ris. Akunt. Dan Manaj., Vol. 7, No. 1, 2018, Doi: 10.21831/Nominal.V7i1.19358.

[3] Supramono And T. W. Damayanti, Perpajakan Indonesia: Mekanisme Dan Perhitungan. Yogyakarta: Andi, 2010

[4] B. Torgler, Tax Compliance And Tax Morale: A Theoretical And Empirical Analysis Benno. Cheltenham, Uk: Edward Elgar Publishing Limited, 2007.

[5] R. Yuliana And Isharijadi, "Pengaruh Sikap, Norma Subjektif Dan Keadilan Pajak Terhadap Kepatuhan Wajib Pajak Orang Pribadi Di Kpp Pratama Madiun,” Assets J. Akunt. Dan Pendidik., Vol. 3, No. 2, Pp. 75-85, 2014.

[6] T. Wulandari, Andreas, And E. Ilham, "Pengaruh Sosialisasi Perpajakan,Pengetahuan Perpajakan, Kualitas Pelayanan Terhadap Kepatuhan Wajib Pajak Secara Langsung Dan Tidak Langsung Dengan Kesadaran Wajib Pajak Sebagai Variabel Intervening (Studi Pada Kantor Pelayanan Pajak Pratama Pekanbaru Sen," Jom Fekom, Vol. 2, No. 2, 2015, [Online]. Available: Https:/Media.Neliti.Com/Media/Publications/125589-Id- Analisis-Dampak-Pemekaran-DaerahDitinja.Pdf. 
[7] D. S. H. Damanik, "Analisis Pengaruh Penyuluhan, Aplikasi Elektronik Dan Pemeriksaan Terhadap Kepatuhan Wajib Pajak Daerah Di Kabupaten Asahan,” J. Ilm. Res. Sains, Vol. 4, No. 1, Pp. 15-28, 2018.

[8] R. A. Anwar And M. Syafiqurrahman, "Pengaruh Sosialisasi Perpajakan Terhadap Kepatuhan Perpajakan Wajib Pajak Usaha Mikro Kecil Dan Menengah (Umkm) Di Surakarta Dengan Pengetahuan Perpajakan Sebagai Variabel Pemediasi," Infestasi, Vol. 12, No. 1, Pp. 66-74, 2016, Doi: 10.21107/Infestasi.V12i1.1801.

[9] E. Puspita, "Analisis Jalur Pengaruh Sosialisasi Terhadap Kepatuhan Wajib Pajak Bumi Dan Bangunan Kota Kediri Dengan Kesadaran Sebagai Variabel Intervening," J. Akunt. Ekon., Vol. 1, No. 1, Pp. 1-8, 2016.

[10] B. Johnston, A. O'connor-Ledbetter, K. Barrett, And K. Pine, Introduction To Public Communication. Indiana State University, 2016.

[11] C. I. R. Rengkung, G. B. Tampi, And V. Y. Londa, "Komunikasi Publik Pemerintah Kota Manado Dalam Penanganan Covid-19,”Jap, Vol. Vii, No. 102, Pp. 29-37, 2021.

[12] M. R. Solomon, Consumer Behavior: Buying, Having, And Being, 12th Editi. Harlow, England: Pearson Education Limited, 2018.

[13] C. Fill And S. Turnbull, Marketing Communication: Discovery Creation, And Conversation, Seventh Ed. Harlow, England: Pearson Education Limited, 2016.

[14] I. P. T. Kusuma, "Faktor-Faktor Yang Mempengaruhi Kepatuhan Wajib Pajak Dalam Membayar Pajak Bumi Dan Bangunan,” J. Penelit. Ekon. Dan Bisnis, Vol. 1, No. 2, Pp. 1-20, 2015.

[15] Muniroh And H. Budiyanto, “Analisa Faktor-Faktor Yang Berpengaruh Terhadap Kepatuhan Wajib Pajak Dalam Membayar Pajak Bumi Dan Bangunan Perkotaan Pada Kecamatan Bangkalan,” J. Kompilek - J. Kompil. Ilmu Ekon., Vol. 4, No. 2, Pp. 150-158, 2012.

[16] Y. Asriyani And K. C. Susena, "Faktor-Faktor Yang Mempengaruhi Kepatuhan Wajib Pajak Bumi Dan Bangunan Di Kecamatan Teluk Segara Kota Bengkulu,” Ekombis Rev. J. Ilm. Ekon. Dan Bisnis, Vol. 4, No. 2, Pp. 136-145, 2016.

[17] Y. Febriani And Kusmuriyanto, "Analisis Faktor-Faktor Yang Mempengaruhi Kepatuhan Wajib Pajak," Account. Anal. J., Vol. 4, No. 4, 2015.

[18] A. Liyani, E. Masitoh, And Y. C. Samrotun, "Faktor Faktor Yang Mempengaruhi Kepatuhan Wajib Pajak Dalam Membayar Pajak Bumi Dan Bangunan Di Desa Gebangharjo, Pracimantoro, Wonogiri,” In Seminar Nasional Ienaco, 2017, Pp. 817-824.

[19] D. Mulyadi, "Revitalisasi Birokrasi Pemerintah Untuk Pelayanan Publik," J. Ilmu Adm., Vol. 3, No. 1, 2004.

[20] D. Mulyadi, "Reformasi Birokrasi Dengan Membangun Organizational Learning Sebagai Kiat Reengineering Perilaku Birokrasi Dalam Rangka Antisipasi Dinamika Lingkungan,” J. Wacana Kinerja Kaji. Prakt. Kinerja Dan Adm. Pelayanan Publik, Vol. 10, No. 2, Pp. 23-42, 2020.

[21] E. Hariyanto, "Komunikasi Pemerintah Dan Efektivitas Kebijakan," Kemenkeu Learning Center, 2019. Https://Klc.Kemenkeu.Go.Id/Pusku-Komunikasi-Pemerintah-Dan-Efektivitas-Kebijakan/ (Accessed Nov. 08, 2020).

[22] P. Kotler And K. L. Keller, Marketing Management, Global Edition, 15 Edition. Harlow, England: Pearson Education Limited, 2016. 